\title{
Chapter 6 \\ Managing Irregularity Through the Provision of Public Education
}

Similar to primary healthcare, the right to receive education is safeguarded under numerous human rights instruments ${ }^{1}$ and although generally limited to persons of school age, it applies irrespectively of their citizenship and immigration status (UNCESCR, 2003). The corresponding legal frameworks regulating the public provision of education, however, can vary significantly between different national but also local contexts, and their inclusiveness often depends on the particular kind and level of education. Importantly, and in addition to being a fundamental right, education also constitutes "the primary vehicle by which economically and socially marginalized adults and children can lift themselves out of poverty and obtain the means to participate fully in their communities" (UNCESCR, 2003, p. 7). Seen from this perspective, public education is thus also intrinsically linked to common understandings of social and economic integration.

Political debates and struggles around irregular migrants' access to education have recently been attributed an important local dimension but continue to be portrayed as being primarily about human rights (Lundberg \& Strange, 2016). Here I am going to show that they are not just struggles over irregular migrants' rights, but also their very possibilities to "integrate into society" ${ }^{2}$ - a process that at least officially still tends to be understood as largely contingent on legal status. According to the experience of Catherine Gladwell, the director of the Refugee Support Network, ${ }^{3}$ education plays a crucial role as a 'normalising routine' for many families who are waiting to be recognised as refugees or whose legal status is otherwise in dispute.

\footnotetext{
${ }^{1}$ Including Art. 13 of the International Covenant on Economic, Social and Cultural Rights (ICESCR), ratified by both Spain and the UK (in 1977 and 1976, respectively).

${ }^{2}$ I am aware of the conceptual problems surrounding the idea of (immigrant) 'integration', which is best understood as the sum of social practices and processes through which newcomers in general and largely independent of their administrative status gradually become part of and accepted by the community they have come to live in (cf. Penninx \& Garcés-Mascareñas, 2015).

${ }^{3}$ Speaking at the Conference 'Precarious Citizenship: Young people who are undocumented, separated and settled in the UK', held on 1 June 2016 at Birkbeck College, University of London.
} 
Their children's regular school attendance not only structures their day and week but also constitutes one of the first points of contact with other members of the community as well as many of the host state's institutions. It thus not only provides a source of hope and belonging, but also official prove of the family's continuous presence in the country. For Michael Strange and Anna Lundberg (2014, p. 201), "[s]chool is both a 'border' by which undocumented child migrants are excluded or included within society, but also where society can make itself felt by the individual child migrant" and arguably also their parents or even extended family. Both as social environments and bureaucratic institutions, schools and other educational establishments can thus significantly shape (irregular) migrants' perception of and (future) position within the host society.

Education thus plays a crucial role for the management of migration, whereby it is not just about learning, nor necessarily about children. Creating opportunities (and often even obligations) for adult migrants to learn the local language and acquire or strengthen specific skills is generally seen as indispensable for their 'successful integration', particularly into the labour market. While such measures obviously target and are often limited to those foreigners holding a legal residence status, it is the situation of irregular migrants in particular that highlights what several authors have identified as an outright contradiction between government approaches toward education on one hand, and immigration on the other (Arnot et al., 2009; Sigona \& Hughes, 2012; Lundberg \& Strange, 2016). While the former necessarily seek to foster equality and social inclusion, the latter - especially when targeting irregular migrants - explicitly aim at exclusion. In this chapter I will show how both, the centrality of education for local integration outcomes and the understanding of education in terms of preparing young people or newcomers for gainful employment, can bolster arguments for the exclusion of irregular migrants from educational opportunities. I will thereby follow the same structure as the previous (and the subsequent) chapter.

\subsection{Between Human Rights and Unwanted Integration: Ambivalent Legal-Political Contexts for the Provision of Public Education to Irregular Migrants}

In May 2016 the UK Department for Education (DfE) announced plans to include information about pupils' nationality and country of birth in the National Pupil Database (NPD). The NPD had been introduced in 2013 to provide a comprehensive "evidence base for the education sector", whereby data can also be shared with third parties "for the purpose of promoting the education or well-being of children in England" (Department for Education, 2015, p. 4). In practice, this means that all schools and colleges across England are now required to request this data from the pupils' parents or guardians, who in turn have been encouraged by several data 
protection and human rights campaigns ${ }^{4}$ to make use of their right to refuse providing such information (Bhattacharyya, 2016; Gayle, 2016). Both the government's official justification and the DfE's specific guidelines on how schools should implement the new requirement are rather vague: According to the latter, "[t]he country of birth would be expected to appear on [...] the child's birth certificate or passport [..., but] there is no requirement for the school to request, or see, a copy of the birth certificate or passport" (Department for Education, 2016b, p. 64). The government claims that obtaining this information will help schools to better assess and address "additional educational challenges" brought about by immigration (ibid.) but has failed to explain how pupils' country of birth or nationality specifically relate to their educational needs or attainment, given that their English language proficiency is already being recorded separately. Critics were concerned that the newly added information might instead be used for the purpose of immigration control rather than promoting schools' or individual pupils' educational achievements.

This development came about a year after a former secretary of state for education had expressed a suspicion that the attractiveness and accessibility of British public schools were to blame for what she called 'education tourism', and therefore ordered an official investigation of the impact that immigration has on the educational system (Ross, 2015). Already in March 2013, not long after Theresa May had first announced the government's 'hostile environment' approach to irregular migration, a series of leaked internal emails from several DfE officials revealed a proposal elaborated by the Inter-Ministerial Group on Migrants' Access to Benefits and Public Services regarding the possibility of requiring schools to check the immigration status of prospective pupils as part of their standard admissions procedure, as reported by The Guardian (Malik \& Walker, 2013). Following widespread criticism, including from professional bodies like the National Union of Teachers (NUT), and given the government's awareness that an outright exclusion of irregular migrant children from school would breach its obligations under human rights law, the plans were quickly abandoned, and their concreteness denied by highranking government officials including Theresa May herself (ibid.). Since then, while the sphere of higher education became a central battleground of the government's 'fight against illegal immigration', the issue of irregularity has not featured very prominently in the realm of compulsory education. Rather than on the basis of administrative status, the effects of past and present immigration on primary and secondary schools and school communities are being discussed in terms of growing numbers of pupils whose first language is not English or whose cultural background otherwise differs from that of their 'native' peers.

Also in the Catalan context, the sharp increase of immigration during the first half of the 2000s has sometimes been discussed with reference to its impact on the education sector. For example, a former Catalan education minister identified the large number of foreign students enrolled in Catalan schools as one of the main

\footnotetext{
${ }^{4}$ See for example Against Borders for Children: http://www.schoolsabc.net/; or \#BoycottSchoolCensus: https://twitter.com/hashtag/BoycottSchoolCensus/ (last accessed 15/12/2017).
} 
causes for the poor results obtained in the OECD's Programme for International Student Assessment (PISA) of 2013 (Ibáñez, 2015). Similar views were also common among the professionals I spoke to, and whose day-to-day work directly exposes them to this increasing diversity. The head teacher at a primary school located in one of Barcelona's most ethnically diverse areas put it this way:

At this moment, and it constantly changes because we enrol new students almost every day, we have about 28 different countries [of origin] and 17 or 18 different languages. So, it's almost like if we were the United Nations. [...] But they progressively develop more and more of a relationship, because you also have to keep in mind that [initially], depending on their culture, for example the fathers don't want to have anything to do with the kids' education and it's the mother who is responsible. Or the fact that for example the [school] director is a man... also helps sometimes. If I were a woman, it would not be the same. But with the help of intercultural mediators, it has changed a lot, it is changing a lot, and to the better (bcnA25).

While such accounts portray the school as a site where the societal impact of immigration is felt more strongly than in other spheres, they also highlight its importance as a place where integration actually happens and is actively promoted on a daily basis. Many of my interviewees stressed the crucial role that schools themselves, as institutions, can thereby play for the integration of newcomers, as reflected in the following statement of another head teacher I interviewed in Barcelona:

It is here, in school, that children spend the most hours, and therefore it is the first arena and context where they familiarise, right? And if they come from another country and arrive here, it is where the protocol of reception has to be most precise and as detailed as possible, because it is the first place to which they come and where they are received (bcnA30).

The question I am interested in here is to what extent this 'protocol of reception' involves taking into account the administrative status that the national immigration regime assigns to all foreign nationals - including children - present on the territory. At least within the early school environment, the equal right to basic education should render differences in immigration, citizenship or economic status largely irrelevant, while other categories such as age, intellect, motivation or (mis)behaviour tend to be more important than they are in many other institutional contexts and spheres social interaction. Roberto G. Gonzales' (2015, p. 13) influential study of migrant irregularity within and vis-à-vis the US education system has shown that in shaping "the parameters of social membership" and controlling access to scarce resources, schools tend to "make their own decisions about deservingness, setting terms of their own for inclusion and exclusion". The sphere of education thereby fits Luhmann's (1982) conceptualisation of a functionally differentiated subsystem of society, within which certain logics and categorisations are dominant while others although crucial for the functioning of other subsystems - loose much of their relevance and regulatory force. As such, the ir/regularity of pupils' or their parents' residence in the country becomes rather invisible within the sphere of education, as the director of the Department for Immigration and Interculturality of the Barcelona City Council emphasised: 
It's not an issue whether they are irregular or not: Here, everyone goes to school. Not like in France, where they persecute and denounce the 'irregulars'... no, no. Here, the school does not... nobody even knows. It is a foreign child, an immigrant, but they [the school staff] do not know if s/he has papers or not. Often this is only discovered in high school, when they plan the end-of-course trip to Italy, for example, and someone who had spent all his/her life in the school says 'no, I cannot go because I don't have papers'... only then they even discover it (bcnA28).

What he tried to present as something quite particular is in fact a characteristic that primary and secondary schools in many countries share: They are shielded from even having to know the immigration status of those individuals whose education and wellbeing is their main responsibility. Also in the UK context, as a migrant youth practitioner of the Children's Society in London explained to me, it often is

only once they turn 18 or 19 that most of their rights and entitlements are actually affected [by their irregularity], because generally they can go through school. They can go through primary and secondary, and even 6th form college, and effectively be the same as everyone else among their peers, but it's when they turn 18 that accessing services becomes an issue (lonA16).

This rather sudden shift from relative inclusion to outright exclusion, which accompanies irregular migrants' transition from childhood to adulthood, has been highlighted by a number of studies documenting the intersection between irregularity and youth in different national contexts (Gleeson \& Gonzales, 2012; Sigona \& Hughes, 2012; Gonzales, 2015).

Before I will look at the legal frameworks that regulate access to both compulsory and post-compulsory education provided in London and Barcelona, and the specific barriers that irregular migrants are facing in both contexts, it is important to recall the antagonistic relationship between migrants' 'integration' and their irregularity: What fundamentally distinguishes the situation of irregular residents (and their relation to the state in which they live) from that of 'regular' immigrants is that the former are generally not expected to integrate but instead explicitly discouraged or even effectively barred from doing so (Schweitzer, 2017). Compulsory schooling thereby seems to constitute one of relatively few public realms of integration that remain explicitly open to them. For many families in that situation, it is precisely the social and official fact that their child attends a local school, which undeniably "makes them part of the society" (lonA08), as a migrant rights advocate I interviewed in London put it. In fact, it can even render the whole family less deportable and/or strengthen their claim for regularisation. On one hand, the formal and personal relationships developed at school significantly count towards the private and family life that migrants in irregular situations must usually prove to have established when they apply for regularisation. On the other hand, being part of a school community also tends to boost popular support for campaigns against a particular family's deportation, as a representative of the London-based advocacy group Right to Remain explained to me:

Schools and colleges can be very supportive if it's a young person that's part of a family that is being removed or at risk [of deportation]. I think schools struggle sometimes though, because they don't know what the rules are, what they have to tell the Home Office, and 
what the Home Office is allowed to ask for and do. But occasionally a school has come out in support of somebody and that is really helpful [for the success of a campaign] (lonA01).

Access to education and training certainly also represents a crucial means for the 'integration' of adults without children. This is particularly true for opportunities to increase language proficiency and acquire professional skills through vocational training. Both elements feature prominently within official integration policy agendas targeting certain regular migrants while usually excluding their irregular counterparts. Many of the education workers I interviewed in London and Barcelona highlighted their responsibility for facilitating all foreign students' successful integration and expressed their reluctance to thereby discriminate on the basis of immigration status. The head of studies of an adult education centre located in a central district of Barcelona put it this way:

As a school we understand... and as a teacher I understand that our role is to give them a course and thus help them to understand and speak the language, whether Catalan or Spanish, and that this will link them more and better to the neighbourhood and the city and country [...] But we do this from our point of view as a school. What we do is [...] [giving the student] more possibilities to integrate better, because I believe this is our job. Another one I don't think we have in this respect (bcnA26).

This perspective, however, even though very common among the teaching professionals I interviewed in both cities, does not tell the whole story. Rather, it contrasts some of the experiences reported by migrants and their advocates, who also mentioned significant legal and/or administrative barriers complicating their access, particularly to further education and training. While they usually accepted that given their status, they could not expect the host state to financially support their education, they also perceived these obstacles as yet another way of trying to keep them out or lock them into a marginal position. The following accounts of a 32-yearold Bolivian citizen living and working in London since 2004 (1), and a woman aged 27 who came to Barcelona in 2012 in order to support her family back in rural Morocco (2), are good examples:

(1) Before, it was still possible to study but it was very expensive. Now, you cannot study anything anymore, not even English. I tried to go and find out, but they asked me for my passport and [legal] residence in the country and all that. They make it more and more complicated [to access education] and close all the doors for us to stay (lonB05).

(2) Without my papers... I cannot do anything. The main thing is the papers: to be able to find some work, to study, to do courses - because there are also many courses that if you don't have papers you cannot do them, [...] like I want to become a nurse or [learn] another profession... I really want to do that, but I... I am... [makes a gesture indicating that her hands are tied]. I cannot do anything (bcnB05).

Rather than leading to absolute exclusion, however, these limitations are part and parcel of a legal-political arrangement that channels irregular migrant workers into a few specific segments of the labour market, some of which have become structurally dependent on this constant supply of cheap and disposable labour (Portes, 1978; De Genova, 2002; Calavita, 2003; Mezzadra \& Neilson, 2013). Together with the administrative hurdles that migrants often face when trying to obtain formal 
recognition of those qualifications and skills they acquired before they migrated, their limited access to training also helps perpetuating the image of a predominantly poor and uneducated migrant population that is likely to become dependent on state benefits. The condition of irregularity further reinforces this effect, as one of my interviewees knew from her experience working as an educator for the CEPAIM Foundation in Barcelona:

\begin{abstract}
Everything you have learned during your life is not being taken into account [...] so you start from zero and are completely stigmatised... Why? Because here immigrants generally occupy very concrete sectors of the labour market, those that [Spanish citizens] like the least; and if you don't have papers [...] you will occupy the niches that are even more hidden. And that reinforces the image of the immigrant who is untrained and doesn't have any education... Why? Because otherwise he wouldn't be collecting scrap metal, she wouldn't be taking care of some elderly person... But the thing is that they are not given the possibility to do something else, right? So, all this is like a circuit that reinforces and stigmatises and excludes (bcnA31).
\end{abstract}

Any debate about whether to promote, facilitate, obstruct or even deny access to certain kinds of education for certain categories of people is always also a debate about which social and economic position they should be assigned or at least allowed to occupy within society.

So why would a state offer any educational opportunities beyond those that are protected by human rights law to migrants in irregular situations? As I will show in the remainder of this chapter, part of the answer is that their effective exclusion would require various kinds of actors within the education sector itself to participate in immigration control, which contradicts (some of) the most fundamental values, professional duties and dominant institutional logics underlying the provision of public education. In addition, and similar to healthcare, the latter is not just premised on individual rights but constitutes another 'functional imperative' of the state, as the former UK Department for Children, Schools and Families (2009, p. 5) recognised in a White Paper outlining its vision of the country's future public education system:

Ensuring every child enjoys their childhood, does well at school and turns 18 with the knowledge, skills and qualifications that will give them the best chance of success in adult life is not only right for each individual child and family, it is also what we must do to secure the future success of our country and society (emphasis added).

\title{
6.2 Legal Frameworks, Formal Entitlements and Practical Barriers for Irregular Migrants' Access to Public Education Provided in London and Barcelona
}

As in the previous chapter, my analysis differentiates between two levels of provision, in this case: compulsory education including related support measures and post-compulsory education or training. 


\subsubsection{Irregular Migrants' Access to Compulsory Education and Related Services}

According to both British and Spanish national law, education is compulsory and free of charge for all children of school age ${ }^{5}$ who reside in the country. The rather subtle difference is that Spanish legislation explicitly extends this right and obligation to children in irregular situations, ${ }^{6}$ whereas the legal framework in the UK simply does not exclude them from the general entitlement of all children to access primary and secondary education (Spencer \& Hughes, 2015). In spite of their formal entitlement, however, a range of potential barriers can prevent irregular migrants from registering their children for school or constrain their regular attendance or educational achievement. These include the inability to fulfil specific documentary requirements established either by the responsible government, ${ }^{7}$ local educational authority (LEA) or individual school; but also, limitations on access to funding for extra-curricular expenses like transport, books or school meals, and the fear that dealing with the education system might somehow reveal their irregularity to the immigration authority.

The first contact with the school administration usually happens in the course of the admission and enrolment process. According to Spanish immigration law, education is not only a right but also an obligation of all foreigners until the age of sixteen and irrespective of their immigration status, which also puts a duty on their parents to register them with a local school. In order to be able to enrol a child, however, a number of documentary requirements have to be satisfied, since the education system generally requires proof of the parents' identity, the age of the child, the family relationship (or legal guardianship) and the place of residence. The official documents that will be requested include an official ID (DNI, NIE or passport) of the parents (as well as the child, if older than 14) and a copy of the family register ('libro de familia') or other official certification of their relationship to each other and to the child. In addition, schools will normally ask for an official immunisation record of the child, ${ }^{8}$ as well as the registration certificate or other official proof of address. ${ }^{9}$ The latter is crucial because school places are allocated on the basis of residence within the immediate vicinity or predefined catchment area of any particular school.

\footnotetext{
${ }^{5}$ From the age of five (in the UK) or six (in Spain) and until 16.

${ }^{6}$ Point 3 of Article 10 of Organic Law 1/1996 on the Legal Protection of Minors establishes that all "foreign minors who are present in Spain have the right to education [...] under the same conditions as Spanish minors".

${ }^{7}$ In both countries some of the general admission procedures and funding rules vary between different regions (PICUM, 2011a, b); I only deal with those that apply to England and Catalonia, respectively.

${ }^{8}$ Otherwise, they make a referral to a health centre in order to establish the immunisation status, as a school administrator explained to me in an interview (bcnA24).

${ }^{9}$ As listed in an official information sheet elaborated by the Catalan Education Department and available online in 17 different languages. See: http://xtec.gencat.cat/ca/projectes/alumnatnou/ acollida/informacio2 (last accessed 15/12/2017).
} 
The British Education Act of 1996 establishes a comparable entitlement along with the corresponding duty of every local (education) authority to provide the same standard of primary and secondary education for all persons who reside within the area and are either "of compulsory school age" or "of any age above or below that age [but] registered as pupils at schools maintained by the authority". ${ }^{10}$ This last provision underlines the important role and relative autonomy of individual schools and LEAs in establishing the concrete admission procedures and requirements, which can thus vary considerably from one school or local authority to another (Sigona \& Hughes, 2012). The formal documentary requirements that parents have to fulfil when applying for a school place in England, however, are fewer than in the Catalan case, since they merely comprise official proof(s) of the family's residential address and the child's date of birth. For example, the Hackney Learning Trust (HLT) - the LEA responsible for the London Borough of Hackney - annually publishes an Admission Guide for Parents, which lists three kinds of documents that should accompany an application (usually made online) for a place in a Hackney school: 'Proof of Address' should be provided in the form of "a copy of either a Council Tax bill or housing benefit entitlement letter" as well as "an original utility bill received within the last two months", while "a copy of either birth certificate, passport or medical card" must show the child's date of birth (Hackney Learning Trust, 2014, p. 27).

Other than in Catalonia, schools and LEAs in England are not explicitly required to systematically request and collect any specific documentation of the parents' identity that would also reveal their citizenship or immigration status, such as a passport. Accordingly, when I asked one of my migrant interviewees how she had experienced registering her two UK-born children in school, she said it worked "without any problem; I just needed a proof of address and their birth certificates when I registered them... they didn't ask for anything else. Their status has never influenced [this], not at all" (lonB04). Once allocated a place in a particular school, however, the actual enrolment process will usually encompass an initial interview with the parents, during which the school can also request additional documents often including their passports - and information regarding the child's previous educational achievements, particular needs, or GP registration (Sigona \& Hughes, 2012). Particularly in the case of over-subscription, individual schools can establish their own criteria according to which they will allocate school places, as long as they do not discriminate on the basis of race, religion, disability or other unlawful grounds. In spite of such legal safeguards, this leaves individual schools with a significant degree of discretion, which can easily lead to disadvantages for families in an irregular situation, who are least likely to file a formal appeal against a decision that they perceive as unfair or discriminatory. For the head of the HLT's admissions department, this is a good reason why school admission, including in-year

\footnotetext{
${ }^{10}$ Under section 13A of the Education Act 1996, available at: http://www.legislation.gov.uk/ ukpga/1996/56/part/I/chapter/III/crossheading/general-functions (last accessed 15/12/2017);
} 
admission and the setting of over-subscription criteria, should be centralised at Council level, ${ }^{11}$ as is the case in her Borough:

[In] our Borough you come to a desk and we coordinate for all the schools where all the vacancies are, as up to date as we can be; [whereas in] the next Borough you would have to go to individual schools, and there is nobody regulating those individual schools. So yeah, once they realise that you don't have immigration status compared to the next parent that comes in and [may be] very well-heeled and speaks fluent English, they could have prejudices there. [...] [In Hackney] a school place will be assigned, and only when they go through an induction meeting in detail a school may pick up further information about immigration status, but before the school place is offered, they are not allowed to ask, and they are not allowed to know; and we personally wouldn't convey that information. In any of the forms that they have $[\ldots]$ as part of their school admissions criteria, they are not allowed to ask questions like that (lonA26).

One reason for individual schools to refuse irregular migrant children could be that they do not officially count towards the overall number of children from lowincome families. The latter is calculated on the basis of pupils' eligibility for free school meals and determines the amount of additional government funding, the socalled 'pupil premium', a school will receive (PICUM, 2011b).

At least in terms of school autonomy the situation in Hackney is similar to that in Barcelona, where the admission and enrolment process itself is managed centrally for the whole municipality. The responsible public body, the Education Consortium of Barcelona ('Consorci d'Educació de Barcelona', CEB) was established in 1998 and precisely in order to allow a more effective coordination of all relevant functions and responsibilities that are formally shared between the municipal and regional government. Although applications for admission can also be made directly at a local school of the parents' choice, it is ultimately the responsibility of the CEB to check all applicants' personal information and documents. The accounts of a head teacher (1) and a senior CEB official (2) indicate how this reduces the discretion of individual school administrators:

(1) When the students are referred to us for enrolment, they already come from the Consortium, and there they also do the first screening and will also already inform us [about application numbers etc.]. There is a department dedicated to directly attending the families, which is where all the enrolments are formally dealt with $[\ldots]$ and from there they are then referred to the schools (bcnA30).

(2) If the school where they go makes it difficult for a family [to register - 'si les ponen problemas'], they come to the Consortium and here we sort it out. We will call the school and let them know that if there is a free place, we are going to refer the child (bcnA29).

While this arrangement thus helps to reduce disparities regarding the local implementation of the rules for access and fair allocation, it cannot completely forestall more subtle gate-keeping mechanisms, as a college teacher pointed out:

\footnotetext{
${ }^{11}$ She thereby also questioned the government's current plans to progressively transform all schools into independent state schools (so-called 'Academies') that are funded directly by central government and operate with more autonomy and less 'interference' from the Local Council (Department for Education, 2016a). See also: https://www.gov.uk/government/news/nicky-morgan-unveils-new-vision-for-the-education-system (last accessed 15/12/2017).
} 
I know of schools $[\ldots]$ where head teachers during the interviews with parents told them things like 'in this school we only speak Catalan, and your son will have many difficulties...'. They played this card so that there would be fewer students who had migrated [including] people without papers. It's a mechanism of exclusion (bcnA27).

Another set of barriers can arise where a family needs additional financial assistance to cover extra-curricular expenses such as learning materials, school meals or transport to and from school. In Catalonia, the fact that one or both parents are in an irregular situation does not automatically exclude a child from these provisions. Instead, any family's entitlement to receive such payments (as well as the level of support) primarily depends on their official income or receipt of minimum income support (Consorci d'Educació de Barcelona, 2015). Irregular migrants' general exclusion from this state-level welfare provision thus indirectly complicates their access to subsidiary funding that is provided locally, where it has to be renegotiated on a case-by-case basis (see Sect. 6.3).

In the UK, in contrast, irregular migrants' formal exclusion from all state-funded benefits (see Chap. 7) more explicitly extends into the sphere of education: While accessing state-funded education is itself not considered a 'recourse to public funds', irregular migrant children are generally not entitled to free school meals or financial support for uniforms, books or transport, ${ }^{12}$ unless the family receives exceptional support by social services (PICUM, 2011b; Sigona \& Hughes, 2012; CORAM, 2013). In relation to school meals, it should be noted that the introduction of Universal Infant Free School Meals in September 2014 extended this entitlement to every child up to the age of seven and enrolled in a public school in England, (implicitly) including the children of irregular migrants (Burns, 2014).

What migrant irregularity is not supposed to interfere with in either of the two contexts I am comparing is the detection and assessment of learning difficulties or any other Special Educational Need (SEN); nor the access to corresponding additional support, as a primary school head teacher in London specifically emphasised:

You know, immigration status is not relevant in any sense as far as the school is concerned. If the child is here, the family is here, then they would be entitled to any kind of support or intervention, including those that engage outside services like educational or psychological or speech and language therapists or social services, you know, immigration status wouldn't have any bearing on that at all (lonA28).

While this reflects the principle that every child enrolled in school should be given the same opportunities to learn, assessing a child as 'in need' of additional support by the state might even strengthen a family's claim for regularisation if their stay in the country is unlawful. Conversely, being assessed as 'not in need' can render such family more deportable, since the child could then also go to school in a country where such support is unavailable. Knowledge of the irregularity of a claimant might thus increase the pressure on those individuals or institutions that are given the power and discretion to make such assessments. Migrants themselves, on the other hand, can easily perceive these decisions as discrimination, as the

\footnotetext{
${ }^{12}$ Regulated under section 509 of the Education Act 1996.
} 
above-cited migrant mother's experience of how the school had dealt with her older son's dyslexia suggests:

It has been very difficult because I had to fight a lot with the school so that they would give me the psychological assessment for [my son]. And so far, no support has been given because the school, from the beginning, made it clear to me that even if he has mild dyslexia there is no additional support [...]. So, I talked to everyone: the director of the school, the director of Special Educational Needs and they told me that $[\ldots]$ apparently, they could not... because the assessment costs a lot and [they] have other cases with more priority in the school...

[Interviewer] ...do you believe that your status had an influence in some way?

Look, they don't say it, because those things are not said. They don't say it but... I think that if an English [person] goes to speak with the director, s/he will have all the support immediately. I feel it; it's something you feel. And I don't have any complex... it's not that I feel less... it's just realistic. I think that it was difficult for that reason (lonB04).

Particularly for migrants in an irregular situation, any such dealings with the school system require a huge degree of trust in the institution and the individual bureaucrat they face or even have to challenge. In the light of the recent developments outlined at the beginning of this chapter it is no surprise that fear (or at least a lack of trust) seemed to be more prevalent in London than Barcelona, even though schools and school staff in both contexts are generally keen to mitigate such fears. The latter ultimately reflects schools' fundamental responsibility to ensure all pupils' regular school attendance, as the head of the HLT's admissions department particularly stressed:

If the adults haven't got immigration status or are in a situation where they are not feeling secure, then the child doesn't come to school because at primary school age you have to be taken to school. [...] And here I think the ethos is that they want everybody to come to school and they want everybody to do well, because [otherwise] the head teachers are under pressure (lonA26).

Irregular migrants' uncertainty about existing entitlements or the risk that activating them might reveal their irregularity is frequently linked to more or less concrete knowledge or fear in relation to past or expected immigration enforcement activities by police or other authorities. Also in the less 'hostile' environment of Barcelona can even a rather vague perception of risk quite easily disrupt school attendance, as the experience of one of my migrant interviewees suggests:

There are a lot of other guys who study with me, from Africa, from Pakistan, who don't have papers, and we were told about [...] a 15-day inspection of people without papers throughout the whole European Union, to look for people who don't have papers... And so, during this time we didn't go out and we didn't come to school [...] because we were afraid (bcnB05).

This shows that fear of deportation can easily trump the pursuit of education, irrespective of whether it is framed in terms of a universal right or an obligation on the part of the parents or the school. In the next section I will look at the realm of post-compulsory education, where both legal entitlement and duty play a significantly lesser role but are not completely absent. 


\title{
6.2.2 Irregular Migrants’Access to Post-compulsory Education and Training
}

The seemingly clear-cut division between compulsory and post-compulsory education does not neatly overlap with irregular migrants' inclusion and exclusion, nor is it resistant to change over time. Rather, the age until which young people in general are expected and encouraged to stay in full-time education has been progressively increased since access to publicly funded education started to be recognised as a fundamental right of all children. In the British context, where this happened at the end of the $19^{\text {th }}$ century, the so-called 'education leaving age' is defined at the regional level, and in England it has only recently been increased from 16 to 18 . This does not oblige young people to stay in full-time education beyond their 16th birthday but makes the local authority responsible for ensuring that they are offered a suitable place in post-16 education or an apprenticeship or traineeship. While the government has not specified what this exactly means for irregular migrants, it might in practice be interpreted as an extension of their right to education beyond compulsory school age, as the following account of an assistant principle at a college in Hackney suggests:

\begin{abstract}
With the raised participation age to 18 now, we are yet to see whether there is any guidance on a student's relationship with their school being good enough to prove their eligibility for funding at age 17 and 18 . We will be testing that this year [...] because if you are under 18 $[\ldots]$ and you are new to the country you are going to have to be able to prove, given the rulebooks, how you qualify [for funding], which is fine. But anyone who had been in secondary school for five years or has done all 11 years of schooling, they are entitled, as I understand it, to continue that education (lonA32).
\end{abstract}

Also a legal and policy officer working for an organisation called CORAM in London described the limit of young irregular migrants' entitlement to receive public education as rather vague but ultimately inescapable:

\footnotetext{
It usually kicks in at a certain point. In our experience young people often don't realise that they have any kind of immigration status issues [until] they apply for a job when they are 16,17 or 18 , or they apply to go to university. It's at that point that they realise they are not like their friends [and] peers... that they can't do what their teachers told them they were going to be able to do if they worked hard. Sometimes that's a kind of turning point in their lives (lonA10).
}

In the Spanish context, this turning point has shifted in 2007 following a landmark decision of the Constitutional Court. It declared unconstitutional a clause of the immigration rules that until then had limited the access to post-compulsory education to foreign minors who were 'resident' in Spain ${ }^{13}$ and thus excluded all those who did not have (or were unable to prove) legal residence rights in the country (PICUM, 2011a). The judges concluded that:

\footnotetext{
${ }^{13}$ Article 9.3 of Organic Law 4/2000 of January 11.
} 
This right of access to non-compulsory education for foreign minors is part of the content of the right to education, and its exercise may be subject to requirements of merit and ability, but not to other circumstances such as the administrative situation of the minor. ${ }^{14}$

Before the law was changed accordingly, young people in irregular situations had been barred from accessing college ('Bachillerato') and professional training, and in many cases could not even obtain the official certification of their high school leaving exam (Morán, 2004). The current law, in contrast, not only entitles them to continue their education until the age of 18 , but also explicitly allows them to finish any course they started before turning 18 , to obtain the corresponding academic qualifications, and to benefit from public funding under the same conditions as Spanish citizens. ${ }^{15}$

The exercise of these rights, however, can still be obstructed by practical barriers such as the inability to fulfil the documentary requirements for college enrolment (which are not always consistent with the legal framework) or to evidence insufficient means to self-finance one's education; as well as difficulties (or delays) in obtaining official recognition of previous academic qualifications (PICUM, 2011a). The latter is particularly important given that selection for post-obligatory studies primarily depends on previous qualifications, as the head of studies of a public high school in the centre of Barcelona highlighted in an interview:

[They] do the pre-registration online and so we have a list of persons who obviously have to have a degree from their country of origin, that is, they have to have completed their secondary education or done an entry test. And based on this previous degree and their online application they are ranked according to their grades and then, well, from one to 30 they can be enrolled, and after that there is the waiting list (bcnA32).

Beyond the realm of formal education, current Spanish legislation also gives irregular migrants the right to access vocational training including temporary work placements, on the basis of a signed agreement between the employer and the school, which certifies that the objective is not employment but training (PICUM, 2011a). Such arrangements, however, also raise a number of practical issues that can easily frustrate employers' willingness to offer such an opportunity to someone who is not fully covered by the national insurance system, for example, as an NGO representative pointed out to me:

[Imagine] you have a youngster [...] learning in a kitchen and they burn themselves... The way [these placements] are designed, they are for people with documentation. They are not suited to undocumented people; that is just not thought of. Somehow... I don't want to say that they are punished, right, but nothing is facilitated, absolutely nothing (bcnA31).

In the UK, in contrast, irregular migrants' access to further education and training is not just 'not being facilitated', but in most cases deliberately obstructed, both in law and practice. As the Platform for International Cooperation on Undocumented

\footnotetext{
${ }^{14}$ Under point 8 of Judgement 236/2007, full text available online: http://hj.tribunalconstitucional. es/en/Resolucion/Show/6203 (last accessed 15/12/2017).

${ }^{15}$ In 2010, the National Assembly removed the general obligation for foreigners to present a residence permit in order to receive state funding for non-compulsory education (PICUM, 2011a).
} 
Migrants (PICUM, 2011b) has repeatedly criticised, they are generally denied access to non-compulsory education including vocational training and 16-18 education, whereby the transition to the latter is particularly problematic if it involves a change of schools.

The simple but fairly effective mechanism of exclusion is to make pupils' eligibility for state funding ${ }^{16}$ contingent on their legal residence in the country, which thus has to be verified in the course of the enrolment process: According to the Education Funding Agency's (2014, p. 11) guidelines, "[t]he main basis for assessing student eligibility is their ordinary residence", which means that "the student must have the legal right to be resident in the United Kingdom at the start of their study programme". ${ }^{17}$ As I will discuss in more detail (in Sect. 6.3), however, individual college administrators are given some discretion when processing the necessary 'evidence', whereas access to university education is strictly contingent on the student's legal residence. In accordance with these rules, young migrants who are not 'ordinarily resident' in the UK are also strictly barred from entering any employment-like relationship, even for training purposes. For example, when in December 2014 the local authority of Lewisham advertised various (paid) apprenticeships to the young (16-25) population of the Borough, it made very clear that potential candidates must not only be residents of Lewisham but also "have full residency entitlement $[\ldots]$ in the UK", and that in order to prove this "all successful candidates will need to produce their passport". ${ }^{18}$ For a lawyer working for Praxis Community Projects, an NGO based in East London, instances like this are part and parcel of

\begin{abstract}
this whole culture of making immigration gatekeepers of people, [which also] means that people are sometimes refused services when actually they are entitled, like refusing people the opportunity to volunteer as well, because people think that they are not allowed to, which is rubbish, you know. Anyone can volunteer, regardless of his or her immigration status (lonA17).
\end{abstract}

Her reference to volunteering is particularly important given that active engagement within the local community is generally regarded as proof of 'integration' and thus often features prominently in public campaigns and legal cases against the deportation of local residents. A (perceived) lack of such efforts or opportunities, in turn, not only helps to reproduce irregular migrants' isolation from society but also renders them less deserving of regularisation.

Probably the most widely accepted proof of 'successful integration' is migrants' knowledge and adequate use of the local language. It is therefore important to

\footnotetext{
${ }^{16}$ Funding is provided either directly to the educational institution or via the responsible Local Authority.

${ }^{17}$ In addition, it is established that "[a]ny person subject to a Home Office deportation order will ordinarily be ineligible for funding until their situation has been resolved to the satisfaction of the Home Office, as funding should only be claimed for students who can complete their programmes" (Education Funding Agency, 2014, p. 11).

${ }^{18} \mathrm{See}$ http://www.lewisham.gov.uk/mayorandcouncil/counciljobs/apprentices/Pages/Who-iseligible-for-an-apprenticeship.aspx (last accessed 15/12/2017).
} 
underline how different the two environments I compare are in terms of the opportunities they provide for migrants in irregular situations to learn English, or Spanish and Catalan, respectively. In the UK, as with other educational opportunities for adult learners, almost all access to publicly funded English courses is strictly contingent on legal residence. In a report titled English language for all, the GLA not only recognised the importance of a comprehensive provision of English for Speakers of Other Languages (ESOL) but also the problems that many refugees and migrants face when trying to access such courses in London. As an example of good practice the report specifically highlighted that less formalised courses offered by NGOs like the Migrant Resource Centre are "inclusive of people regardless of gender, age, immigration status, employment or benefits status" (Greater London Authority, 2012, p. 34). Similarly, the Hackney ESOL Advice Service which coordinates ESOL provision within Hackney reported that in the period of 2014-15, "6\% of learners did not or could not specify their immigration status" and that this meant that "they could only be directed to provision with funding which did not specify any immigration related restrictions ${ }^{19}$ " (Hackney Learning Trust, 2015, p. 33). This is in line with the perception of a senior policy officer at the GLA, who told me in an informal conversation that ESOL provision funded by the central government explicitly excludes irregular residents, which according to her ultimately reflects the broader aim of these programmes: "to get people into employment" (lonC04). She also noted that private or Third Sector providers were often unsure whether they could offer a course or other service to migrants in irregular situations, which also becomes clear from the following quote of a representative of a local community organisation in Lewisham: "[As] a publicly funded organisation [we] cannot be seen to support people without the right to be in this country. I don't know what would happen... if we would lose our funding... or if it would be a crime to support them, I am not sure" (lonC01).

Also in Catalonia irregular migrants' access to further education and training can depend on how and by whom it is financed. When I asked the administrator of an adult occupational training centre (run by a national trade union) about their access criteria, he told me that it is always a question of funding: "The students have to fulfil the requirements that come with the subsidies we receive for offering our courses, because what we offer is [publicly] subsidised training" (bcnC02). Where beneficiaries are required to be officially registered as unemployed, for example, irregular migrants automatically remain excluded "because they cannot fulfil that requirement, just like retired persons are also excluded", he added. Also the president of the Association of Pakistani Workers, which offers legal and occupational advice as well as publicly funded language courses to one of the oldest immigrant communities in Barcelona, acknowledged the broader logic underlying these limitations:

\footnotetext{
${ }^{19}$ In that year this was only the case with funding coming from the Big Lottery Fund as well as one specific programme of the Department for Communities and Local Government, called "English My Way" (ibid.).
} 
They are also right because, of course, for an immigrant to take a course for a year... the government will have spent a lot of money to offer this course and the next day the police may pick him up and send him to his country... What happens? This money... the government loses it. For this reason, the courses are only for those who have papers. But Catalan courses yes, you can learn the language, that you can (bcnA11).

He thereby hints at the fact that in Catalonia, in contrast to the UK context, at least language courses are widely available and explicitly open to migrants in irregular situations. On one hand, this relates to a crucial component of Spanish immigration law, according to which at least basic knowledge of the local language constitutes one of the formal requirements for regularisation, as discussed in Sect. 4.1. On the other hand, it arguably also reflects the very particular status of the Catalan language as not only a vehicle for local integration but also an important symbol of regional autonomy and argument for potential independence from Spain. The head of the Catalan government's General Directorate for Immigration made no secret of this relationship:

[Somebody speaking Catalan] creates an empathy that does not exist with Spanish, because we are a country that historically has been screwed and jeopardised by everyone but that has its own language, which is a language that is not exclusive to the autochthonous [population] but is readily shared. There are always Catalan courses offered everywhere, and people are grateful to the newcomers, to the strangers, who speak Catalan or who learn it (bcnA16).

In this very particular historical and political context, the additional value attributed to promoting the local language - also as a symbol of cultural distinctiveness from the rest of Spain - seems to tip the balance in favour of even irregular migrants' inclusion. An adult language teacher who works in the Raval also referred to the cost-benefit calculations that otherwise often underpin irregular migrants' exclusion from public services and integration measures:

For me this is a problem of... what do you invest in? [...] Either in training or otherwise... of course, in social exclusion, that's a bit what you invest in. Is it more expensive or cheaper? Well maybe it is actually cheaper if you [take into account] the social exclusion of people who have not been able to get trained (benA26).

Also the experiences of migrants I interviewed in both cities largely reflect the rather distinct conditions for learning the local language. A 42-year-old mother of four daughters found it quite easy for her and her family to learn both Spanish and Catalan since they arrived from Uzbekistan in 2011:

They do ask for documents that identify you, that you are you, which is the passport of my country - the only thing I have. Always [...] I go with my passport; they take a copy and use that for [any procedure]. They have no problem with that. They don't ask for a [residence] permit. Without any permit you can study, not work, but study you can (bcnB01).

This stands in stark contrast to the experiences that one of my interviewees in London has made since she entered the UK in 2001 with a false Spanish passport after the Home Office had denied her application for a student visa:

When I realised that I couldn't study in my own name I went to a college and registered with the Spanish name, because I really wanted to study, one way or the other. And so, I was 
studying English for a few months, until someone told me that... if I kept studying like that, I was going to acquire knowledge, but it would not do me any good to get the certificates because they wouldn't really be in my name. That discouraged me a lot and so I started to look for work. I started to work all day and, well, had to forget about my studies (lonB04).

She dropped out of college and instead started working as a cleaner, while her partner found cash-in-hand jobs in construction before he was hired by a large cleaning firm. In contrast to the situation in Barcelona, many migrants I spoke to in London said it was much easier for them to find informal employment than (even self-funded) educational opportunities that would allow them to build their future. As in the previous chapter, I now turn to the perspective of the people who administer or provide publicly funded education in London and Barcelona, in order to highlight how they perceive and navigate the formal opportunities and legal frameworks I have outlined so far.

\subsection{Negotiating the Effective Limits of Access, Educational Need and Immigration Control: The Role(s) and Agency of Education Workers}

While most ethnographic research on irregular migrants' access to education has approached the issue primarily from the migrants' own perspective (Bloch \& Schuster, 2005; Bloch et al., 2009, 2011; Gleeson \& Gonzales, 2012; Sigona, 2012; Sigona \& Hughes, 2012; CORAM, 2013), some studies also hint at the crucial role of institutions and individual professionals. Madeleine Arnot and her colleagues (2009, p. 251) have argued that local authorities as well as individual schools in the UK are "left with the micro-social costs of immigration policy" since they "have to cater for children whose families can be denied access to the social, political and economic rights of a citizen". In the US context, Gonzales (2015, p. 199) has shown that individual school administrators, counsellors and particularly teachers can sometimes "offset, delay[ed], and accelerate[d] the impact of illegality", often depending on the academic potential they see in individual students. As in the previous chapter, I now look at how different kinds of education workers perceive and deal with the various contradictions between the responsibilities of their job and the logic of immigration control.

\subsubsection{Administrators of Public Education and Related Services}

The admission and enrolment procedures constitute the most obvious instances of intersection with immigration control, since they involve checking at least potentially immigration-related documents by the administrative staff of educational institutions. According to a senior official of the Education Consortium of Barcelona, 
the general requirement for parents to show (and submit a copy of) their passport when registering their child for school is necessary but unrelated to immigration control:

For the educational system it is important to identify the person. One thing is whether or not they have a passport; the other is if they have a residence permit. But that is another administration... and each part of the administration should take care of its own [matters] (bcnA29).

In a similar sense, he also argued that proof of residential registration is required "simply because [school] places are given to children who live in the vicinity of the school" and that a lack of such proof would "only mean fewer points for their application" but not inhibit their enrolment (bcnA29). According to NGO staff who are regularly involved in helping refugee and (irregular) migrant families to enrol their children in local schools, however, it is sometimes precisely their initial failure or inability to register their residence within the municipality that later significantly delays their children's access to education (bcnA04, bcnA05). This suggests that in local everyday practice individual administrators often misunderstand registration as an absolute requirement for being allocated any school place. Interestingly, also my interviewee at the Hackney Learning Trust emphasised this particular issue as a potential obstacle:

If we ask somebody for Council Tax [bills] as a standard document for proof of address [...] it could make us aware that more individuals than are meant to be living there, are living there. But even though we are part of the Council, we don't pass that information on to housing benefits or the council tax [department], [...] but we usually try and get around it somehow. We might take a bank statement... and we deal with them on an individual basis, [...] because sometimes if you apply for very popular schools, we have to be really stringent on the address to make sure you really live there, because everybody is trying to live as close as possible to get into the school. It's not really that we are trying to highlight their living arrangements or their immigration status (lonA26).

Given that at least in the sphere of compulsory education these requirements are not formally related to immigration, administrators tend to find out about a family's immigration status not because the law requires them to do so, but rather 'by chance', as the director of a primary school in Barcelona put it: "when we do the registration we ask for all the documentation, and there the family already tells us their situation, or when we enrol them or when they ask for scholarships or support for school lunch... also there they sometimes tell us" (bcnA30). While there is also no obligation or even expectation for them to pass such information on to any law enforcement agency, a lack of even just one of the required documents can cause significant delays to enrolment even for compulsory education. The secretary of a primary school located in a suburb of Barcelona with relatively little immigration, remembered the case of a Chinese family:

The family didn't have papers and of course the first thing we ask for is the family register, to verify that it is really their child, even if they don't have documentation. So, what happened was that they requested an affiliation document from China, which [had to be] signed by a notary [...]. So of course, what happens in these cases is that the process becomes very long, it is very slow; and the child stays out of school [... because of] an administrative issue, an issue of legal bureaucracy, which shouldn't be detrimental for the child (bcnA24). 
In such situations it is often the school that takes a lead in trying to solve the problem by liaising with other agencies at the local level, as the same interviewee went on to describe:

With the enrolment of a child in school - at least in the area where I work - they are very strict. ${ }^{20}$ So, if any of the documentation that is required is missing, there is no enrolment. [...] If they lack the registration certificate from the municipality, [the school] contacts the City Council or makes arrangements with social services. [In her school] we don't have a lot of immigrants, maybe four per cent of the students, but what we do have are cases of family breakdown, we have enough of that, many children with quite dysfunctional family structures, and so we have a fairly fluid communication with social services (benA24).

Her account also suggests that in practice a lack of documentation will trigger a similar procedure as other symptoms of a 'difficult' family background (such as destitution or a suspicion of domestic violence), which usually entails a referral to social services. This parallels an important finding of Gonzales' (2015, p. 167) study in the US, where young people in irregular situations often "benefited from student service offices developed to assist low-income and first-generation students", which also "bolstered their feelings of belonging and claims to membership".

Not only school administrators but also some of the migrants I interviewed in Barcelona described the involvement of mainstream social services as crucial for accessing other public services including healthcare and education. Quite often it is thereby a social workers' individual assessment and written report - in lieu of missing documentation - that allows these systems to deal with and eventually even 'sort out' a client's irregularity, or at least a certain aspect of it. In fact, the Catalan Education Department specifically notes that "in extraordinary cases, alternative documents or reports elaborated by social services will be considered valid" (Departament d'Ensenyament, n.d., p. 3). At least in principle, also local social services in the UK have this role, as I was told at the HLT:

If a child comes into the country and we can't define their age [...] we will call on social services to determine their age. From an admissions point of view, we have done that a few times because $[\ldots]$ the age that the adults are claiming is incorrect, because a lot of times they might... push the age down a couple of years to keep them in education and keep them in the English system longer. But we need to know their exact age in order for them to mix with their appropriate age group. So yes, we do have people from children's services that work in the building and attendants in schools will call on other agencies to work with them as and when needed (lonA26).

The quite significant difference between both environments, however, is that irregular migrants in the UK seem much more eager to avoid any contact with social services. For example, Nando Sigona and Vanessa Hughes (2012) have found several instances where parents would push their kids to go to school even when they are sick, precisely because absence from school might raise attention from social

\footnotetext{
${ }^{20}$ Here she refers to school inspectors (sent by the Education Consortium); at a different point of the interview, she specifically noted that it "also depends on the educational inspection you have, because the inspector may require certain documentation or not".
} 
services who in turn might find out and divulge their irregular status to the Home Office (see Chap. 7).

Apart from admission and enrolment, school bureaucrats also play a key role in negotiating a family's access to financial help with extra-curricular expenses, which is another instance where irregular migrants' exclusion from public funds conflicts with the school's aim to make sure that every child participates fully and benefits equally from public education. The following accounts of two head teachers give an idea of how school administrations in Barcelona struggle to deal with but in collaboration with social workers manage to reconcile these contradictory objectives:

[In order] to receive grants and so on... I believe that a residence permit is required. With all the grants that a family may need... I do think that there is some filter, but I am not sure. For example, there is a grant for school meals from the state and a grant for school meals from the Generalitat (bcnA27).

Often it is only when they need to apply for [financial] help that you would find out [about their irregularity], because obviously in that case you need a social report, and thereby it may come out that there are 15 people registered in the same apartment, and so the whole issue becomes apparent. And so, we automatically [...] refer them to social services, for them to begin to investigate about the issue, and then we try to solve it [...] because the child has the right to be in school and to be attended [...] so there is the possibility that based on a report from a social assistant explaining the situation [...] such support can still be provided (bcnA25).

In the Catalan context, this administrative barrier can thus be circumvented on the basis of an individual assessment of the child's needs, which requires a referral to social services but ultimately allows the family's entitlement to be determined irrespective of their status. However, it also represents an instance where a lack of information and uncertainty on the part of individual bureaucrats can easily undermine irregular migrants' access to a public service that they might be entitled to receive.

In contrast to that, UK legislation does not foresee (let alone prescribe) any procedure through which a LEA or individual school could overcome this strict limitation on a case-by-case basis, as the senior official of the HLT also stressed:

In Hackney, and in most Boroughs, there is an income criterion, and if you meet that you are entitled to free school meals. But if your immigration status affects your potential to earn an [official] income, then that does make it difficult, because then we can't offer you free school meals because you have got no national insurance number. So, we can't do an Inland Revenue check on your salary, because there is no salary (lonA26).

At least in principle, this form of social assistance is - like in Catalonia - meanstested, i.e., triggered by an assessment of the claimant's insufficient financial means. As soon as such assessment either presupposes the claimant's fiscal status to be officially recognised by the state, or even potentially entails his or her immigration status being revealed to enforcement agencies, however, irregularity automatically becomes a barrier - whether that is specifically intended or not. This dilemma will become more apparent when looking the provision of social assistance per se (see Chap. 7). 
The higher the level of education, the sharper become the differences between the roles and immigration-related responsibilities that local school administrators have in the two environments I compare: In Barcelona, the only immediate change from compulsory to post-compulsory education is that access to the latter presupposes previous academic qualifications, while immigration status continues to essentially be a non-issue, as a high school administrator emphasised:

The administrators, what do they do? Well, they are following this list [of student applications ranked according to their grades], regardless of the [residence] permits and all that. There is no place where this information would appear [...] and a person is the $4^{\text {th }}$ or the $7^{\text {th }}$ [on that list] not because s/he has an ID, but [...because of] academic criteria. [...] Also the computer application we use... when you put in a [foreign] passport number it accepts it; it's not that it [refuses] and says 'that's not a NIE', but it accepts perfectly. That means that the computer application has been set up to accept it, because it could also require a NIE. [...] We also haven't received instructions on this... about what we have to do or must not do [...] or that would tell us: 'no, it has to be a person with a residence permit'. No, they are persons interested in the course that they want to enrol in, that's all. [...] So this is not a conflict; it is not putting us in a difficult or conflictive situation (bcnA32).

College administrators in London, in contrast, are legally required to establish every applicant's eligibility to receive public funding for 16-18-education and otherwise refuse their admission, as the vice-principle of a Hackney college explained to me:

We ask each of our students to bring in their passport [...] when they come to enrol with us, so that we can prove who they are. In audit terms it's called their 'existence and eligibility', so that we are not falsifying records; and then we are making sure that students are eligible, in their own right, to these public funds (lonA32).

According to official guidelines, the Education Funding Agency (2014, p. 31) "does not require or expect passports to be photocopied by institutions, although passport numbers or references may be recorded [...] where necessary". More importantly, it establishes that "[f]or circumstances that only affect an individual student the institution is expected to make any necessary decisions itself" and with due consideration of not only "the spirit of this guidance" but also "the best interest of their students" (Education Funding Agency, 2014, p. 8). This effectively does put individual administrators in a difficult position, but also leaves significant room for their interpretation and discretion, as my interviewee went on to explain:

If you read the guidance, we are supposed to make sure that the place we offer a student is a place that they are able to complete. So, if they are an asylum seeker at threat of deportation, immanent deportation, we are not supposed to enrol them, because it's unlikely that they can finish the program... Ahm, it's an interesting one, and we do get students who come in with letters saying that they have been refused, or that their first claim has been refused but is being appealed. And I think then we just take the view that you are still under 18 , you are a child, and we will continue to educate you until the point at which... [...] So we would take a very broad-brush approach, because the rules also say you are not supposed to interrupt the education of someone because of their immigration status and the fact that it might change (lonA32). 
Asked how in practice his team would thus deal with such cases, he told me that they had basically been relying on an earlier response from the Education Funding Agency to a previous request regarding one specific case:

They basically wrote back and gave us a carte blanche by saying: 'If you expect the student to be able to... you know, if the student has an application in, or if the student is here with a parent, you can reasonably assume that the student is allowed or will be allowed to stay. $[\ldots]$ So, if there is an expectation that he would be allowed to stay then we can just say 'yes, you are funded'. So, it was good to make the query and get something back that was more general than answering the question being asked; that was good. And we still use it (lonA32).

On one hand, this confirms Gonzales' (2015, p. 166) observation that "a lack of clear guidelines [can work] in the students' favor"; on the other, it suggests that not only official policy documents can serve street-level bureaucrats as "a form of shield [...] in negotiation between institutions and government", as Jones (2013, p. 28) argued, but also more informal guidance, as long as it comes from what is perceived as the responsible government agency.

\subsubsection{Professional Providers of Public Education}

According to the UK Department for Education (2011), "[t]eachers make the education of their pupils their first concern, and are accountable for achieving the highest possible standards in work and conduct". A crucial part of their professional duty is to promote the emotional and cognitive development as well as the safety and wellbeing of every child in school. Where a family's immigration status is precarious, this very duty acquires an additional meaning, as the head teacher at a primary school in Hackney described:

Obviously once a child is admitted to the school, we have that duty to act in their best interest. Now, we interpret this as [a duty] to minimise disruption to their life generally. If the child has arrived here the basic assumption is that the family has chosen to be here... maybe not freely chosen, but actually this is where they have ended up. And so, you know, we just see it as our duty to provide some kind of stability [...] and that includes minimising the disruption in their life, which obviously would be the case if there were a big struggle about their status...[so] we'd always support them in that (lonA28).

Arnot et al. (2009, p. 258) argued that any "involvement of teachers with the issue of immigration redefines [their] relationship [...] to the state" and particularly their "protecting [of asylum-seeking and refugee] youth, encouraging their abilities and helping them settle into the school community positions teachers in opposition to state immigration policy" (emphasis added). The teaching professionals I spoke to, however, tended to frame their role as less political and more pragmatic, as the quote above as well as the following accounts of a primary school teacher (1) and a language instructor (2) I interviewed in Barcelona suggest: 
(1) You have to understand that for a teacher a child in an irregular or regular situation is the same. In fact, the teacher doesn't even have to know, because it's a thing of the secretary and the management. For the teacher it doesn't matter if [a child] has papers or doesn't have papers, we don't even consider that (bcnA30).

(2) In my class I don't know who has papers and who doesn't, and I don't care. They are students who are in my class and want to learn Spanish or want to learn Catalan, and if they are at [the right] level, I teach them the class (bcnA26).

In the UK, on the other hand, several advocates for the rights of migrants or children in general also noted that immigration status is becoming more of an issue in schools, and that "the very heated national rhetoric about irregularity is absolutely to blame for that" (lonA02). The fact that in response many teachers deliberately disengage themselves from any potential immigration issue can also have negative consequences for a child, as a representative of the Children's Society in London noted:

It's just not picked up there, and that is another reason why it's not recognised at an early stage. Because actually if a teacher realises when a child is 12 that they were born here but aren't actually British, then they could help them to try and register [for British citizenship] and avoid any issues further down the line, but I guess [...] there is a bit of reluctance sometimes from professionals to delve into anything to do with immigration. They are a bit scarred of approaching this subject and [...] there can be quite a lot of misunderstanding about families' rights [....and so] they are like: 'I don't really know what to do with this, so I'm just going to not look at it, I'm just going to concentrate on the other things that I can have an influence on' (lonA16).

It clearly lies beyond the limits of any teacher's professional duty to 'solve' a family's immigration problems, but particularly head teachers can sometimes even contribute to that. Their particular role combines the strong professional ethos of teachers with important administrative and managerial functions and responsibilities: They oversee the admission of new pupils and allocation of specialised services, liaise with families and external agencies, and deal with issues around student behaviour. On the basis of the latter, they may even, under certain circumstances, refuse the admission of a child into a particular class, as one of my interviewees noted (lonA28). Especially in London Boroughs where the allocation of school places is not centralised (as it is in Hackney) but decided at the level of schools, the room for individual discretion is substantial and local practices "can vary significantly between different local authorities, even to the extent where access is dependent on a particular head teacher" (Sigona \& Hughes, 2012, p. 30).

Also in Barcelona, as already indicated, can the attitude of individual head teachers (as well as school inspectors) facilitate or delay a child's enrolment and effective participation in class. A recent resolution by the Catalan Education Department ${ }^{21}$ determines that the head teacher may decide to accept 'alternative documents' if parents are unable to completely fulfil the documentary requirements for admission.

\footnotetext{
${ }^{21}$ Resolution ENS/280/2015, of February 18, see: http://www.educacio.novaciutadania.ben.cat/es/ documentaci\%C3\%B3n-que-debe-presentarse_7374 (last accessed 15/10/2016).
} 
Also the head teachers I interviewed myself, both in Barcelona (1) and London (2), seemed to be aware of their room for discretion in this regard:

(1) From the outset, when they come to enrol a child, the first thing we do is to enrol the child, regardless of whether s/he has all the papers or doesn't have papers. They come with their passport and we register [the child] (bcnA25).

(2) We have had cases in the past of families from Africa, where documentation just wasn't available, so we couldn't even get a confirmation of the date of birth, as there was no birth certificate, and no kind of status, but we would still admit a child into school (lonA28).

Given their far-reaching responsibilities, head teachers also tend to become personally involved with the families and sometimes also their immigration cases, as the one working in London particularly highlighted:

We know our families pretty well and those families where there are clearly big challenges, we know them very well because we have to be involved. And my job is to make sure that the provision that needs to be there is there, and that within increasingly limited resources. [...] So, I am not saying that we should have a kind of completely open-door policy, but you know, where the case is very strong for LTR to be granted it should be granted. And I mean, I am obviously speaking from the perspective of somebody working with the families and getting to know them as individuals, getting to know the kids, seeing the kids grow up, you know, so I am not going to take a more kind of formal, sort of legal view of it, you know, $I$ take a much more personal perspective (lonA28).

It is because of this close personal relationship with the families in combination with their strong (professional) standing within society that individual teachers can sometimes even influence court decisions on immigration cases. According to Kathryn Cronin, the Head of Chambers at the Garden Court Chambers, ${ }^{22}$ cases involving children are often won on the basis of oral evidence provided by a teacher about their good behaviour in school or the negative consequences that their precarious status or even deportation would have for their development. Among the (head) teachers I spoke to, particularly those working in London were very aware of this potential intersection of their own role with the rules and logics of immigration governance, as one of them explained:

Often I am asked to write a letter, basically to confirm that the child is attending the school... and most of the time that's for a solicitor who is making some kind of application. And most times I don't hear anything more, so I guess in many cases applications are successful. But there are a few that keep coming back and it's clear that these families are having a particular struggle, but I am not sure what the difference is, you know. [...] From my point of view, I am just trying to confirm to the authority $[\ldots]$ that the child is in school regularly, that the parents are very responsible and whatever... But also, you know, that having to leave would be a massive upheaval for that child, [...] so I am just trying to argue the case (lonA28).

Also some of the practitioners I interviewed in Barcelona mentioned that reports from schools are sometimes used to support applications for regularisation or renewal of residence permits (bcnA25). Particularly language schools (and teachers) as well as NGOs that deliver officially certified language courses play a much

\footnotetext{
${ }^{22}$ Speaking at the 'Precarious Citizenship' conference in London, on 1 June 2016.
} 
more formal role within the management of irregularity - and thereby also its control, as the following account of a language teacher reveals:

We have many students who come to school because they are interested - apart from learning Catalan or Spanish - in the certificate so that they can obtain papers, regularisations and all these things. [...] One of the things that the administration requests, is a course of a few hours of Catalan or Spanish. [...] So when they come to class, we make them sign. The teacher controls [...] how many days and how many hours they have done and [certifies these], because there are some who want the certificate but don't come to class. But we say 'No, chico, if you want the certificate, I'll give it to you for the hours you've come to class' [...] In this we want to be [strict - hits the table] [...] As a teacher I don't care if you need it [...] because you are from one country or another, if you have papers or don't have papers, I don't care. But what I do want is [that] you come to my class and participate, otherwise no. What I can't do is a false [certificate] that this guy has come to class if he hasn't come. We can't do that, and I don't want to do that! (bcnA26).

It is important to note that the specific kind of control that individual teachers exercise in this context largely corresponds with their very own professional logic, as the same interviewee later convincingly emphasised:

For us it's [like this]: If they come to class, they will learn more languages and integrate better. That is, let's say, our thinking. It's not so much: 'I'm going to force them to comply with the administration...', no: I don't care about that. Want I want is to have them in class, because I firmly believe that if they come to class, they will learn more, and if they learn more, it's better for them. That is the classic position of any teacher; it's in the DNA of a teacher, this idea (bcnA26).

While he acknowledged that the (external) obligation imposed on his students by immigration law often incentivises their attendance in class, he was keen to emphasise that by exercising this kind of control he is not taking over the state's responsibility to regulate immigration:

The administrative situation... should be dealt with by the state, and in this aspect, we are not state, we are school. And I think this is how the majority here thinks. And so, the administration... I don't think it wants... to somehow obtain information [from the school], because they know that they won't get it, because there is no predisposition on the part of the teachers, or those who work here, to give such information. What we want is what I was saying: schooling. And the administration should deal with other things, their own [issues]. So, I won't get involved in whether the administration decides [to require] 45 hours or 60, or [previous residence] of three months or six months, [...] I don't know, it's not my topic. But in return, my topic is schooling and in that we want our freedom, in a certain way (bcnA26).

He thereby relates teachers' professional freedom to the existence of a firewall between schools and 'the state', at least in relation to the immigration situation of their students. While the latter has become much more of an issue in the British context, the general tendency to refrain from controlling immigration - as well as other administrative matters - was essentially the same among teachers I interviewed in London. One of them put it this way:

If the immigration authority rang me, just hypothetically, and said 'can you tell me what you know about this or that family', I would just refuse to say anything obviously, but then I'd be thinking: 'I need to take some advice on this'. I mean I don't know where I would 
stand with that. But it's... we know that we have families here that falsely claim benefits, or that have been giving false details about their address to gain access to education in this or that particular school, you know... And I don't know what other head teachers do but I have never reported any of that, because I just feel, well, people do what they have to do to kind of manage. And I am sure families would not want to divulge that kind of information to me as a kind of... you know, obvious representative of the establishment and the authority, but we hear about this and that, whatever it is, but I have never actually acted upon that (lonA28).

This reluctance arguably reflects his awareness that being involved in controlling aspects of his pupils' or their parents' lives that are not directly related to his professional role and function as a (head) teacher could compromise the crucial relationship with them, and thereby undermine his ability to effectively do his job. In the following, I will argue that the need to shield teaching professionals from having to control their students' immigration status can thereby also partly explain the emergence of dedicated immigration departments within British universities, where even more of this responsibility has been effectively transferred to individual institutions and their employees.

\subsection{3 'Managers' of Irregularity Within the Education System}

Other than in Spain, where a foreigner's admission to university generally precedes (and is administratively unrelated to) the granting or refusal of a student visa by the immigration authority, admission to study at a British university is strictly contingent on legal residence in the country and both processes are closely linked. In fact, universities themselves are given a fundamental role in determining international students' eligibility for a student visa. Before the latter can even make an application to the Home Office, they have to request a Confirmation of Acceptance for Studies (CAS) statement from their prospective university, which thereby officially confirms its intention to 'sponsor' the student's visa application. Only institutions holding a sponsor licence, which has to be renewed annually by the Home Office, can issue CAS statements and thus recruit international students. Following a series of incidents where universities were accused of having enrolled 'bogus' students and therefore lost their licences, the government further tightened these rules in $2014 .^{23}$

In principle, the issuing of a CAS statement is at the university's discretion, but it should be refused if a student is (or has been in the past) in breach of immigration rules, or where the university deems any of the documents submitted or declarations made by the student to be fraudulent. According to the Immigration Policy and

\footnotetext{
${ }^{23}$ Since November 2014 universities risk losing their licence to sponsor overseas students if ten per cent (previously 20 per cent) or more of the individuals they have offered a study place are refused a visa. See: https://www.gov.uk/government/news/new-measures-to-tighten-up-the-immigrationsystem (last accessed 15/12/2017).
} 


\title{
Guidance Manager of a mid-sized university in London this puts a lot of pressure on
} institutions, but also individual members of staff:

\begin{abstract}
We have to get that balance right, and we won't always get it right. There will be instances where... you know, we would have said 'no' to the student when actually... we might have been able to be a little bit more flexible with them. [...] So, it's very difficult, and I think also the guidance that comes up from the Home Office to education providers [...] about what you can and can't accept, isn't always helpful. And therefore, there is a lot of interpretation, and a lot of discretion, and of discrepancy across the education sector in particular, [with] people like myself having to say what this or that particular rule means (lonA29).
\end{abstract}

She also highlighted the intricate power relation between universities and the government, which has clearly facilitated this shift of responsibility:

We, as a sector, are responding to the Home Office because we have to, because we need international students because it's such a big financial incentive. We have to have those students to operate, and that's the same for most universities in the UK, and so in a way any changes that they make, while we will complain about them across the sector, and we will lobby for them to be slightly different, ultimately those changes will go ahead and [in order to] continue to sponsor students [...] we will have to comply with them (lonA29).

Also here, the logic of internal immigration control clearly overlaps with some of the universities' own functional logics, whereby the intersection of the two creates certain conflicts and contradictions, as the following two statements illustrate:

We don't have that many obligations that are border-control-like. We just need to know that the students we have got here should be here, and everything else is what you would expect to do as a normal university anyway; you know, check whether your students are attending classes... that's not about immigration control, that's about your students [...] getting what they are paying for. [...] They have the right that if they are not attending classes somebody knows that and is asking why, so that kind of overlap between good pastoral care and regulating university life and Home Office intelligence is... you know, there is a bit of a blurred line with that, I think (lonA29).

The difficulty is that that often [conflicts] with the kind of academic assessment about whether somebody is suitable for a particular course. For example, somebody might apply to study with us and the academic department might say 'we really want that student', but we have to say whether or not we are going to be able to sponsor them for a visa, and if we can't then obviously, we can't go ahead with the process. [...So] you almost want that to be separate from the academic because a student should be made an offer on the basis of their academic suitability, and all the other stuff should come next. But because of the way the process works we have to consider that at the same time, and that's often difficult for students to understand, and academic colleagues as well because they are only interested in the academic situation (lonA29).

The position of academic staff in relation to such obligations is clear: Even more than most schoolteachers they try to shield themselves from any control responsibility beyond the academic, as a lecturer at another London university emphasised:

The idea that universities are now the gatekeepers is something they hate, because they don't think it's their job, and I think they are right. It's the government's job and the government is outsourcing immigration control to a whole variety of people [...] It certainly increases the workload, which is why [...] it's now all being done by bureaucrats because 
they have to do it like that, it has to be centralised, and that makes sense to me, because otherwise it would just be a pain in the neck (lonA24).

What she seems to hint at is the necessity of (prospective) students' immigration issues to be negotiated and 'managed' centrally - if not by central government then at least by especially trained bureaucrats working within the university. According to organisation theory, one way in which organisations tend to respond to such internal logic incompatibilities is "by developing a cadre of organisational members who are less strongly attached to particular logics" (Besharov \& Smith, 2013, p. 376). Most UK universities have established dedicated teams of advisors who check all foreign students' eligibility and assist them with any visa issue. While these are officially certified (to give immigration advice) by the central government's Office of the Immigration Services Commissioner (OISC), they are 'buffered' from some of the logics that otherwise dominate organisational action and decisions within universities. The way the Immigration Policy and Guidance Manager justified the role of her own team clearly indicates this:

We try to be consistent, and actually the fact that it comes through one team means that those decisions are consistent. Before my team existed, these decisions might have been taken by different colleagues depending on who is involved, so it might have been the academic department even... And so, there was room for different decisions based on personalities, and there was no record of those decisions, it was a bit... of a mess. So, this allows us to be consistent and to apply the same rules to all of our students. [...] There is not so much awareness of the actual technicalities and the rules and so on, you know, [...] I wouldn't expect admissions to understand that necessarily; because their job is to process an application, and an academic's job is to teach somebody (lonA29).

Crucial to my analysis and framework is that this organisational adjustment also facilitates a closer cooperation between part of the university's own administration and the immigration authorities. As my interviewee explained, her team has "names and contacts at the Home Office" and "where we are concerned about a student's status [or] if the student is telling us things and we need more information, with the student's consent we can actually contact the Home Office for what's called a 'student eligibility check", (lonA29).

Importantly, what she initially described as a mechanism through which the Home Office can 'help' them to deal with complex cases also puts a legal obligation on individual student advisors to inform the Home Office "if we categorically know that somebody is in breach of their visa condition" (lonA29). The way she and her team tend to handle such encounters with (potential) irregularity in practice suggests that they regularly struggle with, and sometimes try to bypass, this particular obligation:

If I am completely honest, where we suspect that, we would from an advisory point of view make the student aware [...] that they are potentially in breach and that if we found out that they were, we would have a legal obligation... but we wouldn't just say 'we think you are in breach' and tell the Home Office. We would kind of engage with the individual to try and encourage them to stop doing what we think they are doing, but ultimately, we wouldn't want to kind of police that because that puts an unrealistic kind of burden on us. [...] We did have an application once from a student who... was a failed asylum seeker, and had gone kind of underground, so to speak, and so obviously if we would have suddenly sent 
this student's eligibility check to the Home Office, we would be flagging up that this student is here, that we have their address, we had all that information... And that doesn't... that's not what we are there to do, we are there to assess a student's ability to study with us, not to say to the Home Office 'we found this failed asylum seeker and here is where they are' (lonA29).

Ultimately, this reflects her awareness of the consequences that such information exchange with the immigration authority could potentially have for a student's stay in the country, but also that immigration enforcement as such lies beyond what she perceives as her core responsibility.

\subsection{Education Workers as Migration Managers?}

Following my discussion of the intersections of immigration control with the provision of public healthcare (Chap. 5), the aim of this chapter was to identify equivalent roles and mechanisms in relation to public education. Figure 6.1 summarises the empirical findings presented above by positioning these roles within the same analytical framework, based on whether or not the individuals occupying them in

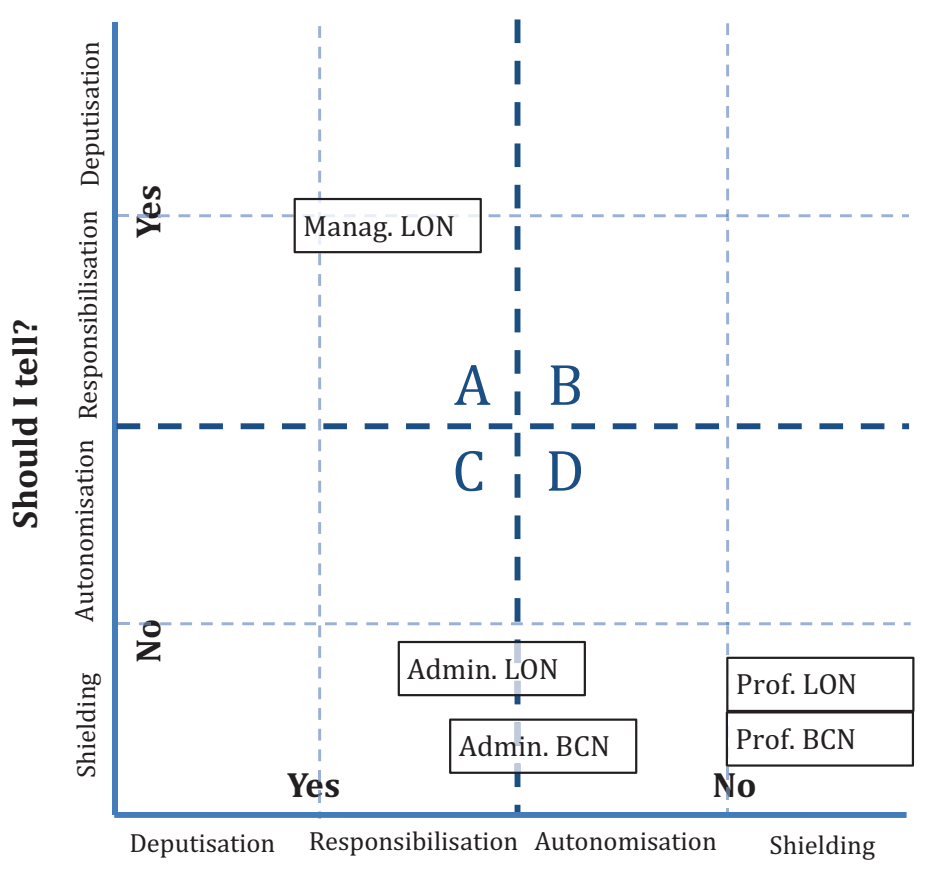

Should I know?

Fig. 6.1 The positions of different categories of education workers in relation to migrant irregularity and its control 
each environment are legally obliged, officially encouraged, or just enabled to (i) find out students' (or their parents') immigration status and (ii) to share such knowledge with immigration authorities.

Other than in the sphere of healthcare, the local administrators of (at least compulsory) education are not expected to find out, record or reveal the immigration status of the students they enrol for school. Just in relation to additional state support for extra-curricular expenses can irregularity become an issue for them and thus - particularly in the UK context - represent a barrier to equal access, which is otherwise well protected by strong human rights provisions as well as the dogma that school is not the right place for immigration control. In relation to postcompulsory education and training, however, and again particularly in the UK, the role of street-level bureaucrats dealing with student admissions can involve the checking of immigration status. This is reflected in their position between sectors ' $C$ ' and ' $\mathrm{D}$ ' of the diagram, whereby those working in London appear further to the left and top.

The professional providers of education are - similar to doctors and nurses in the case of healthcare - effectively shielded from any responsibility to either know or tell the immigration situation of the persons they teach, even though their individual confidentiality is not as firmly protected as that between health professionals and their patients. This also extends into the sphere of post-compulsory and even adult education and is true for both environments studied. Those teaching professionals who also have managerial responsibilities (like head teachers) are more likely to get personally involved with a particular family's immigration case, but in no way expected to know and often particularly reluctant to tell anything related to immigration status.

Specific managers of (potential) irregularity - comparable to the Overseas Visitors Managers in NHS hospitals - only seem to be necessary within UK universities, whereas elsewhere the control of ir/regularity is carried out, if at all, by regular administrative staff. The establishment of immigration advice departments within British universities and the involvement of these departments in controlling immigration, however, is largely a matter of responsibilisation. While both status determination and information exchange with immigration authorities forms part of the managers' work routine, these tasks are not underpinned by explicit legal obligations but rather follow from financial incentives that universities feel unable to resist.

That the existence of a firewall is particularly crucial in the sphere of education has also become apparent from the heated public debate I mentioned at the beginning of this chapter (regarding the content and use of the National Pupil Database in the UK). Notably, it was not so much about students' immigration-related information being included in a national database than the fact that this would potentially make this sensitive information accessible to other state agencies. While the government has assured that this data would not be used for immigration enforcement purposes (Gayle, 2016), a spokesman of the education department, quoted in Schools Week, admitted that "[w]here the police or Home Office have clear evidence of illegal activity or fear of harm, limited data including a pupil's address and school 
details may be requested" (Whittaker, 2016). Given that this has already happened in the past, ${ }^{24}$ the general secretary of the National Union of Teachers said in a press release that the union could only agree to the collection of such data if given "a guarantee from the Government that personal information will not be passed to the Home Office, so that it is clear that schools are not part of policing immigration". ${ }^{25}$ What schools to a large degree are responsible for, and where individual teachers thus are required to report any suspicion to relevant agencies including the police, however, is the health and safety of every child in school, as many of my interviewees assured me. This ultimately highlights the rather close connection between education and (social) control more generally, as well as the potential usefulness of this connection for immigration enforcement. Already in 2010, in a White Paper entitled Protecting our Border, Protecting the Public, the UK Border Agency revealed (under the heading 'Child Protection') that it has initiated "joint projects on the exchange of data and intelligence with schools [...] in order to aid consistent support to migrant children whose families abscond or avoid immigration compliance controls" (UKBA, 2010, p. 18). From the theoretical perspective of my study, such projects must be interpreted as a deliberate effort to develop and justify new forms of immigration control by abusing its potential overlap with the protection of vulnerable individuals against abuse, negligence or destitution. This will become more obvious in the next chapter, where I look at the challenges that underlie the local provision of social assistance to persons who are not only in need of support or protection but also subject to immigration control.

\section{References}

Arnot, M., Pinson, H., \& Candappa, M. (2009). Compassion, caring and justice: Teachers' strategies to maintain moral integrity in the face of national hostility to the "non-citizen". Educational Review, 61(3), 249-264. https://doi.org/10.1080/00131910903045906

Besharov, M. L., \& Smith, W. K. (2013). Multiple institutional logics in organizations: Explaining their varied nature and implications. Academy of Management Review. Academy of Management, 39(3), 364-381. https://doi.org/10.5465/amr.2011.0431

Bhattacharyya, G. (2016). The Home Office are turning teachers into immigration officers. politics.co.uk. Available at: http://www.politics.co.uk/comment-analysis/2016/10/31/ the-home-office-are-turning-teachers-into-immigration-offic

Bloch, A., \& Schuster, L. (2005). At the extremes of exclusion: Deportation, detention and dispersal. Ethnic and Racial Studies, 28(3), 491-512. https://doi.org/10.1080/0141987042000337858

\footnotetext{
${ }^{24}$ A Freedom of Information Request from July 2016 revealed that the Home Office has submitted 20 requests for information to the National Pupil Database since April 2012; see: https: //www. whatdotheyknow.com/request/pupil_data_sharing_with_the_poli\#tincoming-846569 (last accessed 3/08/2016). See also: http://www.parliament.uk/business/publications/written-questionsanswers-statements/written-question/Commons/2016-10-13/48635/ (about Home Office requests made since July 2015, last accessed 15/12/2017).

${ }^{25}$ See: https://www.teachers.org.uk/news-events/press-releases-england/school-census-data (last accessed 15/12/2017).
} 
Bloch, A., Sigona, N., \& Zetter, R. (2009). No right to dream. The social and economic lives of young undocumented migrants in Britain. Available at: https://www.phf.org.uk/wp-content/ uploads/2014/10/Young-Undocumented-Migrants-report.pdf

Bloch, A., Sigona, N., \& Zetter, R. (2011). Migration routes and strategies of young undocumented migrants in England: A qualitative perspective. Ethnic and Racial Studies, 34(8), 1286-1302. https://doi.org/10.1080/01419870.2011.560276

Burns, J. (2014). Free meals ready to be served in infant schools. BBC News, 2 September. Available at: http://www.bbc.co.uk/news/education-29013640

Calavita, K. (2003). A 'reserve army of delinquents' - The criminalization and economic punishment of immigrants in Spain. Punishment \& Society-International Journal of Penology, 5(4), 399-413. https://doi.org/10.1177/14624745030054002

Consorci d'Educació de Barcelona. (2015). Ajuts de menjador escolar: Curs 2015-2016.

CORAM. (2013). Growing up in a hostile environment: The rights of undocumented migrant children in the UK.

De Genova, N. (2002). Migrant "illegality" and deportability in everyday life. Annual Review of Anthropology, 31(1), 419-447. https://doi.org/10.1146/annurev.anthro.31.040402.085432

Departament d'Ensenyament. (n.d.). El Sistema Educativo En Catalunya - Aspectos Básicos. Barcelona. Available at: http://xtec.gencat.cat/web/.content/alfresco/d/d/workspace/ SpacesStore/0076/b4cfbe2b-2a15-4997-a7ce-81f4b4219f56/castella.pdf

Department for Children Schools and Families. (2009). Your child, your schools,our future: Building a 21 st century schools system.

Department for Education. (2011, June). Teachers' standards (pp. 1-11). https://doi.org/ DFE-00066-2011

Department for Education. (2015). The national pupil database. User guide. Available at: https:// www.gov.uk/government/collections/national-pupil-database

Department for Education. (2016a). Educational excellence everywhere (p. 128).

Department for Education. (2016b). School census 2016 to 2017 (Guide, version 1.0). Available at: https://www.gov.uk/government/uploads/system/uploads/attachment_data/file/522546/2016_ to_2017_School_Census_Guide_V1_0.pdf

Education Funding Agency. (2014). Funding guidance for young people 2014 to 2015 - Funding regulations.

Gayle, D. (2016). Parents urged to boycott requests for children's country of birth information. The Guardian, 26 September. Available at: https://www.theguardian.com/uk-news/2016/sep/26/ parents-boycott-requests-childrens-country-of-birth-information

Gleeson, S., \& Gonzales, R. G. (2012). When do papers matter? An institutional analysis of undocumented life in the United States. International Migration, 50(4), 1-19. https://doi. org/10.1111/j.1468-2435.2011.00726.x

Gonzales, R. G. (2015). Lives in Limbo: Undocumented and coming of age in America. University of California Press.

Greater London Authority. (2012, August). English language for all.

Hackney Learning Trust. (2014). Hackney primary school admissions guide 2015. London.

Hackney Learning Trust. (2015). Hackney ESOL advice service - Annual report 2014-15.

Ibáñez, M. J. (2015). La escuela española recula en la integración de los alumnos inmigrantes. El Periodico. Available at: http://www.elperiodico.com/es/noticias/educacion/ocde-informeescolares-inmigrantes-escuela-espanola-recula-integracion-extranjeros-4757256\#

Jones, H. (2013). Negotiating cohesion, inequality and change: Uncomfortable positions in local government. The Policy Press.

Luhmann, N. (1982). The differentiation of society. Columbia University Press.

Lundberg, A., \& Strange, M. (2016). Struggles over human rights in local government - The case of access to education for undocumented youth in Malmö, Sweden. Critical Policy Studies, 1-20. https://doi.org/10.1080/19460171.2016.1142456 
Malik, S., \& Walker, P. (2013). Ministers planning immigration crackdown on "education tourists". The Guardian. Available at: https://www.theguardian.com/politics/2013/mar/27/ ministers-immigration-crackdown-education-tourists

Mezzadra, S., \& Neilson, B. (2013). Border as method, or, the multiplication of labor. Duke University Press.

Morán, C. (2004). Miles de alumnos extranjeros no pueden cursar bachillerato por carecer de papeles. El País. Available at: http://elpais.com/diario/2004/07/28/sociedad/1090965602_850215.html. Accessed 7 Dec 2016.

Penninx, R., \& Garcés-Mascareñas, B. (2015). The concept of integration as an analytical tool and as a policy concept. In B. Garcés-Mascareñas \& R. Penninx (Eds.), Integration processes and policies in Europe: Contexts, levels and actors (pp. 11-29). Springer.

PICUM. (2011a). Building strategies to protect children in an irregular migration situation: Country brief Spain.

PICUM. (2011b). Building strategies to protect children in an irregular migration situation: Country brief United Kingdom.

Portes, A. (1978). Toward a structural analysis of illegal (undocumented) immigration. International Migration Review, 12(4), 469-484.

Ross, T. (2015). Nicky Morgan orders immigration review to examine "education tourism". The Telegraph, 16 August. Available at: http://www.telegraph.co.uk/news/uknews/immigration/11805477/Nicky-Morgan-orders-immigration-review-to-examine-education-tourism.html

Schweitzer, R. (2017). Integration against the state: Irregular migrants' agency between deportation and regularisation in the United Kingdom. Politics, 37(3), 317-331. https://doi. org/10.1177/0263395716677759

Sigona, N. (2012). "I have too much baggage": The impacts of legal status on the social worlds of irregular migrants. Social Anthropology, 20(1), 50-65. https://doi. org/10.1111/j.1469-8676.2011.00191.x

Sigona, N., \& Hughes, V. (2012). No way out, no way in irregular migrant children and families in the $U K$.

Spencer, S., \& Hughes, V. (2015). Outside and in: Legal entitlements to health care and education for migrants with irregular status in Europe.

Strange, M., \& Lundberg, A. (2014). Education as hospitality. Peace Review, 26(2), 201-208. https://doi.org/10.1080/10402659.2014.906886

UKBA. (2010). Protecting our border, protecting the public: The UK Border Agency's five year strategy for enforcing our immigration rules and addressing immigration and cross border crime.

UNCESCR. (2003). Right to education - Scope and implementation. General Comment 13 on the right to education.

Whittaker, F. (2016). DfE refuses to release pupil nationality data agreement. Schools Week. Available at: https://schoolsweek.co.uk/dfe-refuses-to-release-pupil-nationality-data-agreement/

Open Access This chapter is licensed under the terms of the Creative Commons Attribution 4.0 International License (http://creativecommons.org/licenses/by/4.0/), which permits use, sharing, adaptation, distribution and reproduction in any medium or format, as long as you give appropriate credit to the original author(s) and the source, provide a link to the Creative Commons license and indicate if changes were made.

The images or other third party material in this chapter are included in the chapter's Creative Commons license, unless indicated otherwise in a credit line to the material. If material is not included in the chapter's Creative Commons license and your intended use is not permitted by statutory regulation or exceeds the permitted use, you will need to obtain permission directly from the copyright holder.

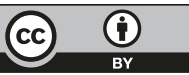

